\title{
TOPIC COVERAGE OF COALITION AGREEMENTS IN MULTI-LEVEL SETTINGS:
}

\author{
THE CASE OF GERMANY
}

\author{
Martin Gross ${ }^{a} \&$ Svenja Krauss ${ }^{b}$
}

\begin{abstract}
When analysing coalition agreements, scholars mostly concentrate on those agreements that are written at the national level. However, there is also a considerable amount of coalition agreements that are written at sub-national levels. This paper analyses the commonalities and differences in coalition agreements in the German multi-level system at the national, regional and local level. From a legal jurisdiction perspective, one would expect that there are major differences across political levels in the topics covered in the agreements. From a multi-level governance perspective, however, one would additionally expect that government parties also devote their attention to policy domains that lie outside their realm of legislative decision-making. We take Germany as a prime example for a political system characterized by joint decision-making authorities within cooperative federalism. Combining data from the Political Documents Archive (www.polidoc.net) with newly data from the Local Manifesto Project (LMP; www.localpartymanifestos.de), we analyse nearly 200 coalition agreements at the national, regional and local level in Germany by applying quantitative text analysis techniques. The empirical results show that governing parties mostly talk about the policy areas they are legally responsible for. However, particularly local and regional governing parties also address issues that are primarily part of federal jurisdiction.
\end{abstract}

*Authors are listed alphabetically. Both authors contributed equally to all work.

${ }^{a}$ Ludwig Maximilians University of Munich, martin.gross@gsi.uni-muenchen.de, twitter: @MartinRGross

bUniversity of Essex, svenja.krauss@essex.ac.uk, twitter: @Svenja_Krauss 


\section{Introduction}

Most political parties do not only compete at one single political level but rather in 'multiple electoral arenas' (Golder et al., 2017, 2) within multi-level governance systems (Deschouwer, 2003; van Houten, 2009). Be it at the national and European level (e.g. Braun and Schmitt, forthcoming), at the national and regional level (e.g. Cabeza, Gómez and Alonso, 2017; Müller, 2013) or even at the regional and European level (e.g. Schakel, 2018), parties simultaneously engage in political competition at different layers of multi-level governance systems. Yet, party signalling to voters via position-taking and issue emphasis in election manifestos and campaign strategies does not end with the respective elections. Particularly parties in government have the option to send specific policy signals to voters and especially to their partisan supporters via an additional option: written coalition agreements.

So far, the comprehensiveness and general issue areas of coalition agreements mainly have been investigated at the national level (e.g. Eichorst, 2014; Indridason and Kristinsson, 2013; Müller, Bergman and Strøm, 2010; Timmermans, 2006). Yet, there is a lack of studies specifically focusing on the topic coverage of coalition agreements on different political layers of a multi-level governance system. When drafting coalition agreements, parties at the national level have at least two options for the way in which they include topics and issues. First, parties most likely will strive for the inclusion of topics that are salient for their voters and party members. Secondly, parties need to react to the political and economic environment they are bargaining in. This means that they should also include topics of high relevance for the public at the time of writing the coalition agreement, even if these topics are not the primary concern of the parties. Yet, things get more complicated in multi-level systems where governing parties at the sub-national level also draw coalition agreements and where national, regional and local actors are participating in central political decisions due to their joint decision-making authorities. It remains an open question to 
what extent parties restrict themselves to the coverage of topics that they are legally in charge of. Therefore, this contribution is interested in answering the following research question: Which topics do governing parties cover in their coalition agreements in multi-level settings?

To answer this question, we take the multi-level setting of Germany as an illustrative case because, on the one hand, it is characterized by a rather clear structure with regard to the legal competences of the different political levels, at least in some policy domains. On the other hand, German politics is also shaped by joint decision-making authorities between national and regional political actors, as well as mutual interrelations between the national, regional and local level regarding execution competences which may have adverse effects on dual accountability and citizens' possibilities to attribute responsibility for governmental behaviour. By using 190 coalition agreements from the national, regional and local level, we demonstrate which topics are covered by government parties in their coalition agreements. ${ }^{1}$ The empirical findings show that governing parties mostly talk about the policy areas they are legally responsible for. However, particularly local and regional governing parties also address policy areas that do not lie in the realm of their jurisdiction.

In the following section, we discuss coalition agreements in multi-level systems in general. In section three, we elaborate on our theoretical expectations regarding parties' topic coverage in coalition agreements in the German multi-level system. We present our data and how we measure topic coverage in coalition agreements in the fourth section. Section five presents the results of the empirical analysis. In the last section, we discuss parties' topic coverage in coalition agreements in detail and elaborate on ways for further research.

2. Coalition agreements in multi-level settings

\footnotetext{
${ }^{1}$ In contrast to other authors (see e.g. Klüver and Bäck, forthcoming) we are not interested in the outcome of coalition negotiations (i.e. the influence of coalition parties on the content of the coalition agreement) but rather in the distribution of attention towards certain topics in the coalition agreement.
} 
While single-party governments are (more or less) free to act during their time in office, parties in coalition governments must coordinate and compromise with their coalition partners. ${ }^{2}$ Even though all governments are confronted with delegation problems, they are more severe in coalition governments. For instance, coalition governments delegate tasks to ministers that are then expected to pursue the agreed policies. Since ministers enjoy informational and expertise advantages vis-à-vis other cabinet members (Laver and Shepsle, 1996), ministers can shirk from the agreed policies. They might even be motivated to do so to please their own party members as they are highly dependent on them for re-election (Müller and Meyer, 2010).

To constrain the shirking of ministers, coalition governments can make use of control mechanisms such as coalition agreements. Coalition agreements are defined as 'the most binding, written statements to which the parties of a coalition commit themselves, that is, the most authoritative document that constrains party behavior' (Müller and Strøm, 2010, 170, emphasis in original). They serve several purposes. First, governing parties use coalition agreements to lower the risk of early government termination by establishing control mechanisms to keep tabs on coalition partners and to manage intra-coalitional conflicts (Bowler et al., 2016; Indridason and Kristinsson, 2013; Krauss, 2018). Secondly, coalition agreements can be conceived as policy signals to governing parties' rank-and-file members. Thirdly, governing parties highlight their primary policy goals and try to signal to voters that they intend to keep their electoral promises (for an overview, see Eichorst, 2014). Although the content of coalition agreements is usually divided into three categories-policies, procedural rules and portfolio allocation-coalition parties mainly

\footnotetext{
${ }^{2}$ Coalition governments in parliamentary democracies are prone to less transparent politics for voters because it is more likely than in single-party governments that negotiations within the coalition or between government parties are privately and internally (Strøm, 2000, 281), and thus cannot enter voters' considerations on election day (León, $2018,707)$. Coalition agreements are one way to counter this lack of transparency since government parties publicly commit themselves to jointly agreed policy proposals.
} 
concentrate on policies when writing their coalition agreements (Strøm, Müller and Bergman, 2010).

For the national level, there exists a large literature on the comprehensiveness of and the general issue areas covered in coalition agreements (see, e.g Eichorst, 2014; Indridason and Kristinsson, 2013; Müller, Bergman and Strøm, 2010; Timmermans, 2006) while coalition agreements at the regional and local level only attracted little scholarly attention (for an exception see Baumann, Debus and Gross, 2017; Gross 2016, 2017, 2018; Stefuric 2009) The content of coalition agreements at the sub-national level, however, and its comparability to coalition agreements at the national level have not been scrutinized so far. This is surprising since there is a considerable amount of coalition agreements that are written at sub-national levels in countries with multi-level governance structures. Such political systems are characterized by joint decision-making, where national, regional and/or local actors are participating in central political decisions, and they are quite common in West European democracies (e.g. Belgium, Denmark, or The Netherlands). ${ }^{3}$ Secondly, multi-level settings are sometimes criticized for hampering dual accountability due to joint decision-making authorities, blurring the clarity of (institutional) responsibility and affecting citizens' representation in the political process. The role coalition agreements at different political levels might play has not been studied so far.

Particularly joint decision-making authorities partially run counter to the 'clarity of responsibility' (Powell and Whitten, 1993). Most of the literature on clarity of responsibility deals with the link between citizens' economic voting and the clarity of institutional settings in multi-level systems and empirically shows that complex institutional settings have adverse effects on the

\footnotetext{
${ }^{3}$ In some countries, for example in our illustrative example of the German multi-level governance system (see below), the local level does not have a say in policy-making at the national and state level; yet, the local level often has large execution competences, i.e. in some policy areas it is local political actors' decision to what extent and in which way they execute national and state laws, respectively.
} 
straightforward connection between concrete policies and voters' evaluations of these policies, whereas the mere existence of coalition governments and coalition agreements negatively affects the clarity of responsibility (Hobolt, Tilley and Banducci, 2013).

From a retrospective voting perspective, it is expected that voters incorporate a government's performance evaluation into their voting decision. Government parties should therefore restrain from including pledges in their coalition agreements which they cannot fulfil due to the lack of legislative competences. Additionally, from a democratic theory perspective specifically focusing on multi-level governance systems, one would ideally expect that voters will hold politicians accountable for things the respective politicians actually can control (Rodden and Wibbels, 2010, 630). This dual accountability can most likely be achieved if the various levels of government have 'mutually exclusive spheres of authority', so that voters have the best chances to 'assign responsibility to the appropriate level of government' (Rodden and Wibbels, 2010, 632). Empirically, however, this 'dual accountability does not seem to operate very clearly' (Rodden and Wibbels, 2010, 631), not even in decentralized governance systems where government competences are clearly separated across the different political levels (for an overview, see Thorlakson, 2017, 548). Taking the example of decentralized and federalized political systems, voters face problems in clearly assigning responsibilities to the various governments at different political levels because (i) sub-national levels might primarily only be in charge of implementing federal legislation, but at the same time the multi-level nature of the political system requires a minimum of coordination between the different political levels (Thorlakson, 2017); (ii) the number of veto players in federal and decentralized systems, particularly in countries with second chambers, might distort citizens' views on politicians' authorities over specific policy fields (León, 2018); (iii) politicians might play credit claiming and blame shifting in policy areas where several political levels have joint authority (Volden, 2005); and (iv) power allocation to different tiers of government is not clear-cut in many policy areas (Toubeau and Wagner, 2018). Additionally, one 
might add that voters focus more on federal policies (Stecker, 2015, 1309) and have the tendency to hold regional political actors accountable for policies that are not dealt with at the regional level (see, e.g. ; Toubeau and Wagner, 2018). This is particularly the case when distributed powers between political levels are intertwined (León, 2010).

Regarding coalition agreements in multi-level settings, political actors thus should have an incentive to rather focus on issues, topics and policies that lie in their realm of decision-making to get voters' credit if they fulfil their pledges. In line with the responsible party model (APSA, 1950), government parties should translate voters' policy preferences into government. However, this does not only depend on a party's ability to enter the government, but also on the parties' ability to pursue their policy plans within their institutional capabilities. For instance, there are policies that can only be changed at the European level. Countries that are members of the European Union are not allowed to sign trade agreements with other countries single-handedly. Similar arrangements can be found within the nation state. Therefore, the distribution of competences might have an influence on what is actually written down in coalition agreements. While parties will try to listen to their voters, they will also try to avoid including promises they cannot fulfil due to lacking competences. This reasoning is in line with the literature on pledge fulfilment showing that coalition agreements are one of the main explanatory variables for pledge fulfilment because if a pledge had been translated into the coalition agreement, the chances of fulfilment are substantially higher (see e.g. Moury, 2011; Schermann and Ennser-Jedenastik, 2014a, b).

Yet, the literature on pledge fulfilment exclusively focuses on the politics and policies at the national level. Arguing from a multi-level governance perspective, however, it might additionally be the case that coalition partners at one political level exclusively include topics that can only be fulfilled at another political level just because these coalition partners also coalesce at this other political level. For example, including national policies in sub-national coalition agreements could 
be a signal of government parties to their core partisan supporters and voters that they will make use of their possibilities to influence national politics via joint decision-making and within a second chamber. Furthermore, in situations where sub-national elections are perceived by voters as second-order elections to judge national politics by focusing on national issues, sub-national parties might not only anticipate this and adjust their election campaigns (Däubler, Müller and Stecker, 2018; Stecker, 2015). Sub-national political actors drafting a coalition agreement might additionally have a clear incentive to also address national issues in their written agreements in order to show to voters that political actors take their concerns seriously. ${ }^{4}$ Hence we would expect to see that national, regional and local coalition agreements also cover topics that are not primarily in their realm of legislative decision-making.

3. Which topics should parties cover in their coalition agreements in Germany?

Different political levels in multi-level governance systems have different legal competences over specific policy fields. These legal competences might be clearly separated, i.e. that only one political layer is legally responsible for legislating specific policy fields or characterized by joint decisionmaking between several political layers. In Germany, most legislative powers are concentrated at the federal level. Although states are almost exclusively responsible for education policy regarding the school system, cultural policy, police and media, they must share decision-making authorities in the most important policy fields, such as taxation, social policy or labour policy, with the federal level (Stecker, 2015, 1308). Local governments are administrative institutions, yet local councils do adopt statutes or propositions that are comparable to laws on the national and regional level (Gross and Debus, 2018, 68). Even though some policy domains are exclusively legislated by the federal

\footnotetext{
${ }^{4}$ Additionally, particularly the local level in many European democracies is characterized by an interplay between local council majorities and directly elected mayors. Since mayors are the most prominent figure in local politics, thus resembling presidents in (semi-)presidential systems (cf. Hobolt, Tilley and Banducci, 2013; Oktay, 2018; Valdini and Lewis-Beck, 2018), 'clarity of responsibility' and pledge fulfilment might be more dependent on the performance of the mayor and less on local government parties' performance and promised policies in their coalition agreements.
} 
level in Germany, the German Länder implement most of the federal laws and regional governments' policies nevertheless vary to a large degree (Jeffery et al., 2014). Furthermore, particularly the last reforms of German federalism increased joint decision-making between the federal and the state level (Benz and Sonnicksen, 2017; Kropp and Behnke, 2016), which gives regional governments still considerable leeway in policy-making. This clearly impacts sub-national parties' campaign strategies, position-taking, and parliamentary behaviour (see, e.g. Müller, 2009, 2013; Schröder and Stecker, 2018). In other words, '[w] hereas the policy agenda of the main subnational parties is nearly as all-embracing as that of their federal party organisation, the German version of federalism centralises most legislative competences at the national level and sets restrictive limits to the implementation of this policy agenda at the regional level' (Stecker, 2015, 1306). This means that although regional party branches have restricted legal leeway in implementing their preferred policies in many policy areas, they still 'have an all-embracing agenda' (Stecker, 2015, 1310).

Independently from the empirical fact to what extent federal legislation is not in line with regional party branches' policy preferences, regional party branches should have an incentive to talk about federal policies and national topics in their regional election manifestos and, consequently, as regional government parties in their coalition agreements. If sub-national government parties are not satisfied with policies pursuit by the federal organizations, sub-national government parties have the possibility to signal their diverging policy preferences to their regional or local voters in their election manifestos and coalition agreements (Stecker, 2015, 1306). For the case of Germany, it is a well-documented fact that sub-national parties adopt policy positions in their election manifestos that deviate to some degree from their federal parties' positions (see Debus and Gross, 2016; Müller, 2009, 2013). Furthermore, the policy locations of and included topics in coalition agreements in the German multi-level system differ between different compositions of (coalition) 
governments, both at the state and the local level (see, e.g. Bowler et al., 2016; Gross, 2016). This indicates that sub-national government parties do try to pursuit different policies.

Yet, due to the great extent of joint decision-making authorities in the multi-level system of Germany because of the concurrent legislation by the federal and state level and the fact that 'policy issues often transcend the territorial boarders of Länder jurisdictions' (Kropp and Behnke, 2016, 675), the state and local administrations' role as executing authority for implementing these laws (Benz and Zimmer, 2011), and the federal-state nexus regarding shared taxes (Benz and Sonnicksen, 2017), we also expect that both national and regional, as well as local coalition agreements to some extent also address policy fields that are not in their exclusive realm of policymaking. There are at least four reasons to expect this. First, even though sub-national party branches might be very clear and consistent in their policy messages by just focusing on a specific set of sub-national policies (Däubler, Müller and Stecker, 2018), sub-national party branches might also highlight national topics that are of utmost importance at the time of writing of the coalition agreements (for instance, how to deal with an economic crisis or an influx of migrants). Secondly, because German voters primarily care about federal policies, 'sub-national parties in Germany and their leaders are incentivised to centre competition for regional votes around federal issues' (Stecker, 2015, 1309), and this should also be reflected in regional coalition agreements. Thirdly, according to Article 50 German Basic Law the German Länder are involved in federal and European legal matters and administration, and regional government parties might use the content of their regional coalition agreements to show the federal government that they are not willing to allow it to limit states' autonomous legislative responsibilities in those policy areas, where the consent of the German Länder is necessary to pass a law. Fourthly, German states do not only have independent legal competences, state and particularly local administrations often are in charge of implementing federal policies at the state and local level. Since citizens are directly impacted by 
administrative decisions, regional and local political actors have an incentive to address such issues in regional and local coalition agreements.

To sum up, we first expect that parties drafting coalition agreements at the federal level should primarily talk about policy fields where the federal level has exclusive legal competences (according to article 73 German Basic Law), and where international and supranational issues are affected. For example, the federal level should include more regulations about international affairs in their coalition agreements as they are solely responsible for these topics. Secondly, regional government parties should highlight in state coalition agreements particularly policy fields where they have exclusive decision-making authorities. Following from this, we posit two general hypotheses:

Hypothesis 1: The more legislative competences the levels have regarding specific policy domains, the more political actors emphasise these topics in the respective coalition agreements.

Hypothesis 2: The higher the level of joint decision-making between the federal and the state level is, the more balanced is political actors' attention towards these topics in national and regional coalition agreements.

Turning to the local level, Article 28 (2) German Basic Law states that local governments are responsible for settling all the affairs of the community as their own responsibility within the framework of the law. Yet, local political actors are not represented in some sort of 'second or third chamber', where they could negotiate with national and state political actors, respectively. Rather, local municipalities are part of state governments which represent municipalities in intergovernmental negotiations with the national government, and the federal government is not 
allowed to lead direct negotiations with municipalities. ${ }^{5}$ Hence, in purely formal terms, 'local governments are administrative institutions' (Benz and Zimmer, 2011, 160). and regarding the de jure non-existing legal competencies of German municipalities, we would expect local government parties to talk extensively about local issues and only marginally about national and state policies in local coalition agreements.

De facto, however, we argue that also local government parties should emphasise policy domains that are (more or less) exclusively related to the federal and state level (if we would strictly follow the provisions of the German Basic Law) because local political actors are in charge of executing many federal and state laws, on the one hand, and municipalities additionally have their own policymaking authorities when levying local taxes, fees and charges, on the other hand (see e.g. the ideologically-induced variation in same-sex unions' registration fees (Debus et al., 2013)). Therefore, the local level fulfils 'important political functions for multi-level policy-making in the federal system' (Benz and Zimmer, 2011, 160), and 'German local governments have considerable leeway in deciding on their issues' (Benz and Zimmer, 2011, 161). ${ }^{6}$ Consequently, our third hypothesis reads as follows:

Hypothesis 3: The higher the execution competence at the local level regarding specific policy domains, the more political actors emphasise these topics in local coalition agreements.

Table 1 summarizes the theoretical expectations regarding the extent of government parties' emphasis of different policy domains in their coalition agreements at the federal, state and local level (for the selection of the policy domains see the following section 'Data and measurement').

\footnotetext{
${ }^{5}$ Note that this last point will change with the reorganisation of federal-state financial arrangements from 2020 on, when the federal level will be allowed to help municipalities financially, at least to some extent (Renzsch, 2017, 769). ${ }^{6}$ Local governments 'fulfil tasks either by own competences of self-government-some of them being obligatory and others optional—or by competences delegated by the Land government' (Benz and Zimmer, 2011, 160-161).
} 
For example, we expect that the policy field 'Development, Defence, Foreign, Security' will be exclusively covered by national coalition agreements because this policy domain lies in the realm of federal jurisdiction (Article 73 (1) German Basis Law), which is also the case for the policy domain 'Agriculture, Environment, Energy, Climate'. Regarding European issues, however, we would expect that also state government parties address some European issues in their coalition agreements because, for instance, regional governments and their administrations are part of the formulation and implementation of EU regional policies (see e.g. Leonardi, 2005). We expect the policy domains of 'Economy', 'Infrastructure, Transportation, Digitization', 'Fiscal' and 'Justice' to be all-embracing policy fields in the German multi-level governance system because all three political levels are either in charge of regulating individual subsections of the respective policy domains (for example via taxes and fees, or by attracting companies) or, in the case of 'Justice', the state structure already determines that all three political levels have a say. Furthermore, the federal system of Germany grants the federal states far-reaching responsibilities in education policies. Yet, we also expect parties at the federal level to cover education policies in their coalition agreements because the federal level, for instance, is responsible for the core financing of higher education institutions. Additionally, we expect national coalition agreements (and partially regional coalition agreements) to cover welfare, family and health issues the most because particularly the federal level is mainly responsible for social-state precautions. Lastly, we mainly expect national coalition agreements to cover the policy domain 'Domestic, Asylum, Immigration' because it is the federal level which is legally in charge of the rule of law and immigration policies. However, since this policy domain also covers policing (which the Länder are responsible for) and asylum policies (which partially the municipalities have to deliver), we also expect this policy domain to be covered in coalition agreements at the state and local level, respectively. 
Table 1: Theoretical expectations on topic coverage in German coalition agreements ${ }^{7}$

\begin{tabular}{lccc}
\hline Policy domain & Federal level & State level & Local level \\
\hline Europe & $\mathrm{Y}$ & $(\mathrm{Y})$ & $\mathrm{N}$ \\
Development, Defence, Foreign, Security & $\mathrm{Y}$ & $\mathrm{N}$ & $\mathrm{N}$ \\
Domestic, Asylum, Immigration & $\mathrm{Y}$ & $(\mathrm{Y})$ & $\mathrm{Y}$ ) \\
Economy & $\mathrm{Y}$ & $\mathrm{Y}$ & $\mathrm{Y}$ \\
Education & $\mathrm{Y})$ & $\mathrm{Y}$ & $\mathrm{N}$ \\
Infrastructure, Transportation, Digitization & $\mathrm{Y}$ & $\mathrm{Y}$ & $\mathrm{Y}$ \\
Fiscal & $\mathrm{Y}$ & $\mathrm{Y}$ & $\mathrm{Y}$ \\
Welfare, Family, Health & $\mathrm{Y}$ & $(\mathrm{Y})$ & $\mathrm{N}$ \\
Agriculture, Environment, Energy, Climate & $\mathrm{Y}$ & $\mathrm{N}$ & $\mathrm{N}$ \\
Justice & $\mathrm{Y}$ & $\mathrm{Y}$ & $\mathrm{Y}$ \\
\hline
\end{tabular}

Note: $\mathrm{Y}=$ Yes, indicating that a policy domain should be prominently covered in coalition agreements at the respective political level; $(Y)=(Y e s)$, indicating that a policy domain might be covered to a certain extent in coalition agreements at the respective political level; $\mathrm{N}=\mathrm{No}$, indicating that a policy domain should only be marginally covered in coalition agreements at the respective political level.

\section{Data and Measurement}

Which topics do parties cover in their coalition agreements? To answer this question, we rely on data from the German multi-level government system. Germany ranks low both on institutional clarity' and 'government clarity' compared to other European states (Hobolt, Tilley and Banducci, 2013) due to its multi-level political system where each level of government has its specific rights but where there is also joint decision-making and mutual interrelations regarding execution

\footnotetext{
${ }^{7}$ We acknowledge the fact that the allocation of responsibilities is not always as clear cut as this typology might suggest. Due to the highly complex nature of the German multi-level system, we, however, try to simplify this by relying on broad categories.
} 
competences across the three different political levels. Furthermore, coalition agreements prevail on all political levels in Germany. Nearly all federal- and state-level governments draft a coalition agreement (see e.g. Kropp, 2002; Kropp and Sturm 1998) and if parties decide to form a coalition at the local level, they most often also sign a written statement on their future cooperation (see Gross, 2016, 2018). Additionally, most federal, state and local governments (in large cities) are minimal winning coalitions (Debus and Gross, 2016; Debus and Müller, 2013), thus making coalition agreements comparable across the different political levels. Local coalition agreements closely resemble coalition agreements at the federal and state level since parties include coalitioninternal dispute resolution mechanisms, talk about the allocation of portfolios (such as department heads) and focus on highlighting planned policy actions, which leads to the same patterns of policy position-variations between different local coalition agreements as at the state and the federal level in Germany (see Gross 2016, 187-188; Gross, 2017, 214). ${ }^{8}$

We use coalition agreements from 1990 to 2017 at the national level (8), at the regional level (81) and at the local level (101), i.e. cities with more than 100,000 inhabitants. ${ }^{9}$ Hence, the data set comprises in total 190 coalition agreements. National and regional coalition agreements are obtained from the Political Documents Archive (Benoit, Bräuninger and Debus, 2009; Gross and Debus, 2018b). Data on local coalition agreements comes from the Local Manifesto Project (LMP) (Gross and Jankowski, forthcoming).

\footnotetext{
${ }^{8}$ Note that the institutional setting at the German local level with a directly elected mayor and a local council is a neither a pure presidential nor a pure parliamentarian system (Bäck, 2005; Egner 2015) but rather a 'mixed democracy' (Gross and Debus, 2018a) or 'institutional hybrid' (Egner, 2015) between a 'quasi-presidential' (Benz and Zimmer, 2011; Egner and Stoiber, 2008) or a 'semi-presidential' (Debus and Gross, 2016; Bäck, 2005) government system, depending on which German state authors are primarily basing their analysis on. This does not change, however, the equivalence of local coalition agreements to coalition agreements at the federal and state level because local government parties can still shape policy-making and portfolio allocation at the local level, even if the directly elected mayor is from an opposing party.

${ }^{9}$ For a detailed justification why cities in Germany with at least 100,000 inhabitants are 'parliaments in disguise' and why parties frequently form coalitions see Egner (2015) and Gross (2018). Note that coalition agreements at the local level were not always publicly available, thus we might be slightly underestimating the number of coalition agreements at the local level.
} 
Table 2 presents descriptive statistics for the coalition agreements at the different levels. The data shows that there is significant variation regarding the length of coalition agreements at the national, the regional, and the local level. For instance, the shortest coalition agreement at the national level is 10,379 words in length while the shortest one at the local level contains only 275 words. Overall, the longest coalition agreements are those at the national level, followed by the ones at the regional and the local level.

We are interested in how salient certain topics are in the coalition agreements. We chose the following ten prominent policy areas: (1) Europe, (2) Economy, (3) Infrastructure, Transportation, Digitization (ITD), (4) Fiscal, (5) Education, (6) Domestic, Asylum, Immigration (DAI), (7) Agriculture, Environment, Energy, Climate (AEEC), (8) Welfare, Family, Health (WFH), (9) Justice, and (10) Development, Defence, Foreign, Security (DDFS). The ten policy areas are not one-to-one aligned to ministries at the federal and state level (Pappi and Seher, 2009) or to departments at the local level because the denomination and composition of ministries is dependent on government composition and the policy preferences by government parties. Hence, the policy areas chosen for the analysis are broader than the classification of ministries and departments, not least because government parties at the federal and state level in the last years decided to combine policy domains in ministries that are not as closely aligned as in former times (see Pappi and Seher, 2009).

Table 2: Number of words in German coalition agreements

\begin{tabular}{lccccc}
\hline Level & Min. & Max. & Mean & Std. Dev. & N \\
\hline National level & 10,379 & 61,922 & 35,517 & 21,349 & 8 \\
Regional level & 4,310 & 60,972 & 24,913 & 13,970 & 81 \\
Local level & 275 & 22,689 & 5,771 & 4,746 & 101 \\
\hline
\end{tabular}

Note: Total number of words in German coalition agreements at the national, regional, and local level (1990-2017). 
To be more specific, we are interested in the share of attention that is being attributed to the ten policy areas in the various coalition agreements. In order to obtain the shares, we rely on the dictionary coding approach (see e.g. Laver and Garry, 2000). Dictionary coding is a quantitative approach for analysing a large amount of texts. In contrast to qualitative approaches, quantitative approaches make use of 'mechanical criteria' (Laver and Garry, 2000, 625) to group words or text units into pre-defined categories. In the case of dictionary coding, words or specific phrases that pertain to certain policy or issue areas are allocated to these categories. This dictionary is then applied to the texts and looks for the frequency of occurrence of the words and categories in these texts (Laver and Garry, 2000). For this paper, we developed a dictionary that includes words pertaining to the individual policy categories in the coalition agreements (see Table 4 in the Appendix for a list of key words).

Constructing a dictionary does not come without problems. It is necessary to identify and include key terms that adequately describe the content of the categories. At the same time, these key terms should exclusively apply to just one category. We relied on a procedure suggested by Laver and Garry (2000) to construct the dictionary: a combination of a priori and empirical criteria. A priori, we allocated words to our categories by relying on empirical examples from Jakobs and Jun (2018), Pappi and Seher (2009) and Bergmann et al. (n.d.). Jakobs and Jun (2018) divided German parties' manifestos to the general elections in 2017 and the respective coalition agreement in several policy (and non-policy) domains and assigned specific segments of text to these domains. We took their identified policy domains as a starting point for our analysis, but we re-arranged some of the policy areas to better fit the names of ministries and departments at the federal, state and local level. Next, we partly followed the procedure of Pappi and Seher (2009) who start their classification of policy domains by using the names of German ministries at the state level and the 'joint occurrence of domains in the name of ministries' (Pappi and Seher, 2009, 409) to develop a categorical scheme 
of policy areas covered in party manifestos. ${ }^{10}$ Subsequently, they assigned the party manifestos' subtitles to specific policy domains. We, too, added words to the dictionary by reading through randomly chosen coalition agreements and identifying terms that appeared in most subtitles within the coalition agreements by backing up the assertion of Pappi and Seher $(2009,410)$ that parties use (sub-)sections in manifestos - and coalition agreements - to signal to voters what the most important policy domains are. Following Bergmann et al. (n.d.), who fit structural topic models to parliamentary speeches in the German Bundestag to unravel the policy area a parliamentary debate was mainly about, we used their list of frequent and exclusive words for each policy domain and subsequently skimmed through a random selection of documents to add words to some categories in order to get a more balanced number of words between different policy areas. In the end, the construction of our dictionary was an iterative process, in which we started off with a basic dictionary, ran the analysis and then checked for inconsistencies. We then added missing words and deleted or re-allocated others.

Applying dictionary coding to coalition agreements provides one with the frequency with which the words belonging to a specific policy area in the dictionary are mentioned in the coalition agreement. We present the share of these frequencies, meaning that we summed up all mentions and then divided the frequencies of each policy category by the total number of mentions. Hence, we end up with a share of each policy category in our dictionary.

5. Empirical Analysis and discussion of results

\footnotetext{
${ }^{10}$ Note that Pappi and Seher (2009) explicitly are interested in party manifestos' 'coalition-relevant content' because of the 'policy domain-specific policy signals' to 'potential coalition partners' (Pappi and Seher, 2009, 408), thus coming close to our intention in this article to study policy-relevant topics in coalition agreements.
} 
The results of our dictionary analysis are presented in Figure $1 .{ }^{11}$ The red bars show the shares for the coalition agreements at the federal level, the green bars represent the shares for the coalition agreements at the state level, and the blue bars are the shares for the coalition agreements at the local level. It is important to note that the results must not be interpreted in the sense that low values indicate that government parties do not care about such policy domains; rather, the results demonstrate the ratio between different policy domains, i.e. where government parties' focus is placed on in coalition agreements. Overall, the graph shows that there is not only variation in salience between the different levels within the multi-level governance system of Germany but also between the different policy domains. We first turn to each political level separately before we take a closer look at the comparison between the different political levels and policy domains.

Coalition agreements at the federal level in Germany primarily focus on the policy domains 'Agriculture, Environment, Energy, Climate' (19\%), 'Welfare, Family, Health' (16\%) and 'Economy' (15\%). These latter two policy domains are policy areas where the federal level has rather strong legislative decision-making authorities and financial responsibilities vis-à-vis the subnational levels, whereas the category 'Agriculture, Environment, Energy, Climate' is largely regulated at the EU-level. Regarding the latter fact it makes sense that national government parties talk a lot about these supranational issues because, first, that is where the money mainly comes from to support farmers, and, second, problems and challenges within this policy domain are predominantly dealt with at supranational summits and conferences. Note, however, that this seems not to be the case in two policy areas where exclusive legislative competences lie at the national level: 'Europe' and 'Development, Defence, Foreign, Security'. Although the results are in line with our theoretical expectation that the salience for both categories is substantially higher at the federal than at the sub-national level, both topics do not play a dominant role in national

\footnotetext{
11 The results were obtained after we cleaned and set up our text corpus with the 'tm' R-package (Feinerer and Hornik, 2018) and ran the dictionary analysis with the 'quanteda' R-package (Benoit et al., 2018).
} 
coalition agreements in Germany (compared to other policy domains; see also Jakobs and Jun, 2018, for the current coalition agreement). 
Figure 1: Share of policy fields in German coalition agreements

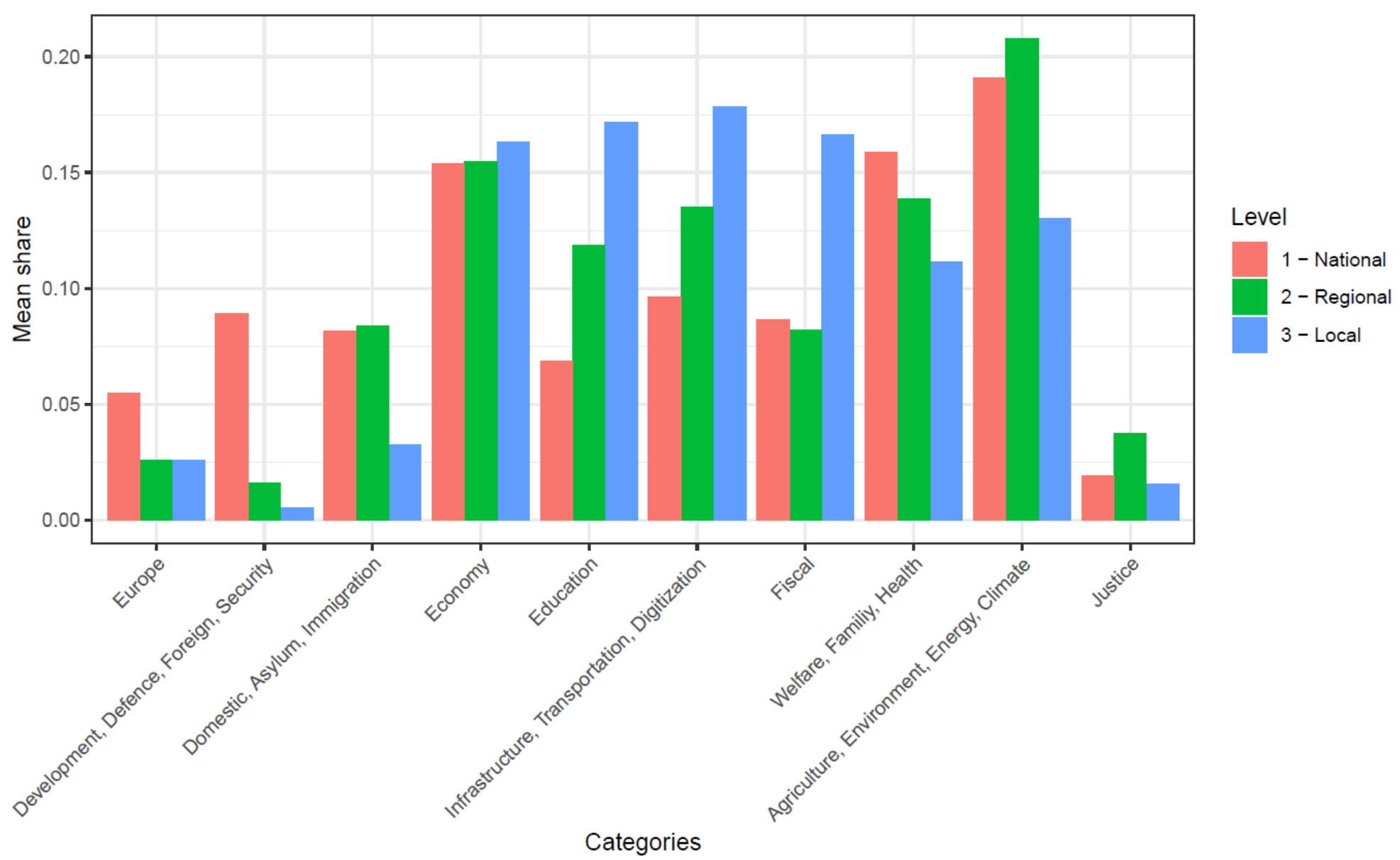

Note: The figure presents the share of ten policy areas in German coalition agreements at the local, regional, and national level (1990-2017). Note that the basis for comparison of the shares is the sum of the ten policy areas. 
The descriptive analysis for the German Länder level clearly shows that state government parties also mostly focus on 'Agriculture, Environment, Energy, Climate', 'Economy' and 'Welfare, Family, Health', but also on 'Education' and 'Infrastructure, Transportation, Digitization', i.e. policy areas they are either solely responsible for (education) or where there exists a large degree of joint decision-making authority with the federal level. Hence, and highlighting the state-federal nexus in Germany, regional politicians use coalition agreements to signal their policy preferences to voters and politicians at the federal level regarding those policy areas where regional governments must be involved via the Bundesrat due to the regulations of the German Basic Law. Furthermore, since state-level parties in Germany already position themselves in their regional election manifestos regarding the EU's regional policy (Gross and Debus, 2018), it is hardly surprising that they also address EU-dominated policy domains once they are in government. It is the regional level which exceedingly benefits from the EU's regional policy and EU's common agricultural policy, and, therefore, regional government parties have an incentive to address welfare and agricultural issues in their coalition agreements because particularly EU Cohesion policy has an impact on the economic development of regions, even in a rich country such as Germany (for an overview see Crescenzi and Giua, 2017).

Yet, the most prominent example of (more or less) exclusive legislative competences at the state level is 'Education'. Partly contrary to expectations solely based on the legal jurisdiction of this policy field, the salience for education is highest at the local level, followed by the state level, while it is lowest at the federal level. The high salience at the local level, however, can partly be explained by the fact that the local level is usually responsible for the implementation of the legislative acts that were enacted at the regional level. More importantly, however, it is the responsibility of local municipalities and their administrations to refurbish schools and kindergartens which is one of the most fiercely discussed topics in German local politics. The same applies for the policy fields of 'Infrastructure, Transportation, Digitization', 'Fiscal' and 'Economy' when it comes to the 
improvement of (local) public transport, broadband expansion and attracting companies to locate in specific areas. Lastly, local politicians also devote a considerable amount of space to 'Agriculture, Environment, Energy, Climate'. From a strictly legal perspective, this is surprising because the local level does not have any say in these policy fields. Yet, particularly this policy domain demonstrates that political actors do not only care about the legal competences they have when writing a coalition agreement but also about topics that are salient for their partisan supporters or the electorate in general. For example, the discussions about air pollution, nitrogen-reduction measures and 'no drive' zones in German cities are highly disputed in the last years. Although the local political level does not have a final say in legislative decision-making in the aforementioned policy fields, local interests are directly affected. Hence, we would argue that voters expect from local politicians to address these important issues in local coalition agreements.

Considering all three political levels, the closest resemblance between coalition agreements at the federal, state and local level can be seen in the policy domain 'Economy'. Economy is almost equally important for government parties at the national, regional and local level, at least based on the share of attention they devote to this issue in their coalition agreements. Since there are no exclusive legislative competences with regard to economy, the results are in line with our theoretical expectations. Furthermore, since sub-national political actors are also (partly) evaluated by voters for their perceived state of the regional economy and because ' $[\mathrm{b}]$ oth federal and regional governments have a role to play in shaping economic conditions in their jurisdictions' (Toubeau and Wagner, 2018, 22-23), sub-national political actors have clear incentives to address economic issues in coalition agreements. Table 3 includes an overview of our results. Bold letters signal that our theoretical expectations are supported by the results. Overall, we find (tentative) support for our three general hypotheses.

Table 3: Evaluation of the theoretical expectations on topic coverage in German coalition 
agreements

\begin{tabular}{lccc}
\hline Policy domain & Federal level & State level & Local level \\
\hline Europe & Y & (Y) & N \\
Development, Defence, Foreign, Security & Y & N & N \\
Domestic, Asylum, Immigration & Y & (Y) & $(\mathrm{Y})$ \\
Economy & Y & Y & Y \\
Education & Y) & Y & N \\
Infrastructure, Transportation, Digitization & Y & Y & Y \\
Fiscal & Y & Y & Y \\
Welfare, Family, Health & Y & $(\mathbf{Y})$ & N \\
Agriculture, Environment, Energy, Climate & Y & N & N \\
Justice & Y & Y & Y \\
\hline
\end{tabular}

Note: $\mathrm{Y}=$ Yes, indicating that a policy domain should be prominently covered in coalition agreements at the respective political level; $(\mathrm{Y})=(\mathrm{Yes})$, indicating that a policy domain might be covered to a certain extent in coalition agreements at the respective political level; $\mathrm{N}=\mathrm{No}$, indicating that a policy domain should only be marginally covered in coalition agreements at the respective political level. Bold letters indicate that our theoretical expectations are supported by the results. 


\section{Conclusion}

Coalition agreements play a vital role in coalition governance at the national, regional and local level in West and East European democracies. We have analysed the distribution of attention towards specific topics and policy domains, respectively, in coalition agreements at the national, regional and local level in the German multi-level governance system. We have theoretically expected that the emphasis coalition parties put on different topics, should partly depend on the legislative competences of the respective governance levels. An opposing argument, however, based on insights from multi-level governance research, established the theoretical expectation that government parties in multi-level political systems characterized by cooperative federalism and joint decision-making should also talk about policy domains that lie beyond their realm of legal jurisdiction.

By taking the case of Germany, which is a prime example for cooperative federalism, we analysed the content of coalition agreements at the federal, the state and the local level from 1990 to 2017. Using a dictionary-based approach, allocating words to ten distinct policy fields, the results show that by and large coalition agreements highlight most prominently those policy fields for which the respective governing parties are mainly legally responsible for. However, particularly coalition agreements at the local level additionally address a range of policy issues where local municipalities and their administrations are only indirectly responsible for (from a legal perspective); yet, since many problems become most often socially virulent at the local level, it comes as no surprise that local governing parties also address these issues in their coalition agreements. Furthermore, in the German multi-level system administrative functions are largely transferred to state and local administrations, which therefore are de facto in charge of dealing with topics that de jure fall into the realm of federal decision-making. 
Regarding the discussion on 'dual accountability', the responsiveness of parties to voters' needs and the 'clarity of responsibility' in multi-level systems, these first results indicate that governing parties in Germany do not stick to those policy areas they are exclusively responsible for but additionally address other policy fields. They might do so for several reasons. For example, they might address other policy fields for symbolic reasons (i.e. creating the impression that government parties at the state and local level actually can change something at the federal level). Additionally, they might also try to influence parties at other political levels. For instance, the regional organisation of the SPD, if in government, might try to influence the federal organisation of the SPD by mentioning specific topics in their coalition agreement, which might be a challenge for intra-party cohesion. Further research should therefore analyse if and how the coalition agreements on different levels influence each other but also, for example, party manifestos. Nevertheless, we would argue that regional government parties address other policy fields both because of the joint decision-making authority structure of the German multi-level governance systems and due to sub-national politicians' willingness to play an active role in legislative decision-making which is almost exclusively possible at the federal level via the German Bundesrat. Although regional government parties theoretically have the possibility to propose bills in the German Bundesrat, this procedure is rather difficult. First, they must compromise with their coalition partner(s) because only the government as an entity is able to act in the Bundesrat. Second, they also need to find a majority in the Bundesrat for their proposal which is increasingly difficult due to the increasing number of different coalition combinations in the Bundesrat. Local politicians can only raise the awareness of problems, grievances and (financial) needs at the local level by either publicly announcing these topics_-and hoping for some media coverage —or by speaking directly to their constituents via the content of their coalition agreements, thus signalling that they are pulling all the plugs to economically and socially improve local municipalities. 
The German multi-level political system is a prime example of joint decision-making authorities and mutual interrelations within cooperative federalism. Not surprisingly, coalition agreements at the national, regional and local level also include topics that are not exclusively lying in the respective realm of legislative decision-making. Future studies might want to take a look at political systems characterized by dual federalism (e.g. Switzerland, United States of America) or asymmetric federalism (e.g. Canada, Italy, Spain, United Kingdom) to investigate to what extent intergovernmental arrangements, at least between the national and the state level, might play a role in government parties' addressing of topics in coalition agreements.

Furthermore, individual parties' strategies, position-taking and issue ownership might also play a role for the topic coverage of coalition agreements, as well as the context the coalition agreements are written in. Parties most likely will strive for the inclusion of topics that are salient for their voters and party members, and they need to react to the political and economic environment they are bargaining in. This means that they should also include topics that are of high relevance for the public at the time of writing the coalition agreement, even if these topics are not the primary concern of the parties. Future research could investigate to what extent these considerations might impact the topic coverage of coalition agreements at different political levels. 
References

APSA. 1950. "Towards a More Responsible Two-Party System." American Political Science Review 44(3):1-99.

Bäck, Henry. 2005. The institutional setting of local political leadership and community involvement'. In Urban Governance and Democracy: Leadership and Community Involvement, ed. Michael Haus, Hubert Heinelt and Murray Stewart. London, New York: Routledge pp. 65-101.

Baumann, Markus, Marc Debus and Martin Gross. 2017. "Strength of weakness? Innerparteiliche Heterogenität, divergierende Koalitionspräferenzen und die Ergebnisse von Koalitionsverhandlungen in den deutschen Bundesländern." Politische Vierteljahresschrift 58(2):179-204.

Benoit, Kenneth, Kohei Watanabe, Haiyan Wang, Paul Nulty, Adam Obeng, Stefan Müller and Akitaka Matsuo. 2018. “Quanteda: An R Package for the Quantitative Analysis of Textual Data." Journal of Open Source Software 3(30):774.

Benoit, Kenneth, Thomas Bräuninger and Marc Debus. 2009. “Challenges for Estimating Policy Preferences: Announcing an Open Access Archive of Political Documents." German Politics 18(3):441-454.

Benz, Arthur and Christina Zimmer. 2011. Germany: Varieties of Democracy in a Federal System. In The Oxford Handbook of Local and Regional Democracy in Europe, ed. John Loughlin, Frank Hendriks and Anders Lidström. Oxford: Oxford University Press pp. 146-172.

Benz, Arthur and Jared Sonnicksen. 2017. “Advancing Backwards: Why Institutional Reform of German Federalism Reinforced Joint Decision-Making." Publius: The Journal of Federalism 48(1):134-159.

Bergmann, Henning, Lucas Geese, Christian Koss and Carsten Schwemmer. n.d. "Using Legislative Speech to Unveil Conflict between Coalition Parties." Unpublished manuscript. 
Bowler, Shaun, Thomas Bräuninger, Marc Debus and Indridi H. Indridason. 2016. 'Let's Just Agree to Disagree: Dispute Resolution Mechanisms in Coalition Agreements." The Journal of Politics 78(4):1264-1278.

Braun, Daniela and Hermann Schmitt. forthcoming. "Different Emphases, Same Positions? The Election Manifestos of Political Parties in the EU Multilevel Electoral System Compared." Party Politics.

Cabeza, Laura, Braulio Gómez and Sonia Alonso. 2017. "How National Parties Nationalize Regional Elections: The Case of Spain.” Publius: The Journal of Federalism 47(1):77-98.

Crescenzi, Riccardo and Mara Giua. 2017. Different Approaches to the Analysis of EU Cohesion Policy: Leveraging Complementarities for Evidence-Based Policy Learning. In EU Cohesion Policy: Reassessing Performance and Direction, ed. John Bachtler, Peter Berkowitz, Sally Hardy and Tatjana Muravska. Milton Park: Routledge pp. 21-32.

Dassonneville, Ruth and Michael S. Lewis-Beck. 2017. "Rules, Institutions and the Economic Vote: Clarifying Clarity of Responsibility.” West European Politics 40(3):534-559.

Däubler, Thomas, Jochen Müller and Christian Stecker. 2018. “Assessing Democratic Representation in Multi-Level Democracies." West European Politics 41(3):541-564.

Debus, Marc and Jochen Müller. 2013. 'Do Voters' Coalition Preferences Affect Government Formation?" West European Politics 36(5):1007-1028.

Debus, Marc, Christoph Knill and Jale Tosun (2013): Registration Fees for Same-Sex Unions, Local Party Politics and Societal Demand. Local Government Studies 39(6):756-776.

Debus, Marc and Martin Gross. 2016. "Coalition formation at the local level: Institutional constraints, party policy conflict, and office-seeking political parties." Party Politics 22(6):835-846.

Deschouwer, Kris. 2003. "Political Parties in Multi-Layered Systems." European Urban and Regional Studies 10(3):213-226. 
Egner, Björn. 2015. "Parliaments in Disguise? How German Councillors Perceive Local Councils." Local Government Studies 41(2):183-201.

Egner, Björn and Michael Stoiber. 2008. “A Transferable Incumbency Effect in Local Elections: Why it is Important for Parties to hold the Mayoralty." German Politics 17(2):124-139.

Eichorst, Jason. 2014. "Explaining Variation in Coalition Agreements: The Electoral and Policy Motivations for Drafting Agreements.” European Journal of Political Research 53(1):98-115.

Feinerer, Ingo and Kurt Hornik. 2018. “Tm: Text Mining Package. R Package Version 0.7-5.”.

Golder, Sona N., Ignacio Lago, André Blais, Elisabeth Gidengil and Thomas Gschwend. 2017. Multi-Level Electoral Politics: Beyond the Second-Order Election Model. Oxford: Oxford University Press.

Gross, Martin. 2016. Koalitionsbildungsprozesse auf kommunaler Ebene. Schwarz-Grün in deutschen Großstädten. Wiesbaden: Springer VS.

Gross, Martin. 2017. Großstadt ist nicht gleich Großstadt: Erklärungsfaktoren für die Unterschiede bei kommunalen Koalitionsverhandlungen und Koalitionsvereinbarungen. In: Variationen des Städtischen - Variationen lokaler Politik, ed. Marlon Barbehön and Sybille Münch. Wiesbaden: Springer VS pp. 193-219.

Gross, Martin. 2018. “'Sowing the Seeds of Love’? Determinants of Local Coalition Formation and Termination between the CDU and the Greens, 1994-2016." German Politics 27(3):339-358.

Gross, Martin and Marc Debus. 2018a. "Gaining new insights by going local: determinants of coalition formation in mixed democratic polities." Public Choice 174(1-2):61-80.

Gross, Martin and Marc Debus. 2018b. 'Does EU regional policy increase parties' support for European integration?” West European Politics 41(3):594-614.

Gross, Martin and Michael Jankowski. forthcoming. "Dimensions of political conflict and party positions in multi-level democracies: evidence from the Local Manifesto Project." West European Politics. 
Hobolt, Sara, James Tilley and Susan Banducci. 2013. "Clarity of Responsibility: How Government Cohesion Conditions Performance Voting." European Journal of Political Research 52(2):164_ 187.

Hooghe, Liesbet, Gary Marks and Arjan H. Schakel. 2010. The Rise of Regional Authority. A Comparative Study of 42 Democracies. New York u.a.: Routledge.

Indridason, Indridi H. and Gunnar Helgi Kristinsson. 2013. "Making Words Count: Coalition Agreements and Cabinet Management.” European Journal of Political Research 52(6):822-846.

Jakobs, Simon and Uwe Jun. 2018. "Parteienwettbewerb und Koalitionsbildung in Deutschland 2017/18: Eine Analyse der Wahlprogramme.” Zeitschrift für Parlamentsfragen 49(2):265- 285.

Jeffery, Charlie, Niccole M. Pamphilis, Carolyn Rowe and Ed Turner. 2014. "Regional Policy Variation in Germany: The Diversity of Living Conditions in a 'Unitary Federal State'.' Journal of European Public Policy 21(9):1350-1366.

Klüver, Heike and Hanna Bäck. forthcoming. "Coalition Agreements, Issue Coverage and Cabinet Governance." Comparative Political Studies.

Krauss, Svenja. 2018. "Stability through control? The influence of coalition agreements on the stability of coalition cabinets." West European Politics 41(6):1282-1304.

Kropp, Sabine. 2002. Koalitionsbildungen in Bund und Ländern: Verfahren, Institutionalisierungsprozesse und Gewinnverteilungen. In Parteiendemokratie in Deutschland, ed. Oscar W. Gabriel, Oskar Niedermayer and Richard Stöss. Wiesbaden: Westdeutscher Verlag pp. 340-359.

Kropp, Sabine and Nathalie Behnke. 2016. "Marble Cake Dreaming of Layer Cake: The Merits and Pitfalls of Disentanglement in German Federalism Reform.” Regional \& Federal Studies 26(5):667-686.

Kropp, Sabine and Roland Sturm. 1998. Koalitionen und Koalitionsvereinbarungen: Theorie, Analyse und Dokumentation. Opladen: Leske + Budrich. 
Laver, Michael and J. Garry. 2000. "Estimating Policy Positions from Political Texts." American Journal of Political Science 44(3):619-634.

Laver, Michael and Kenneth A. Shepsle. 1996. Making and Breaking Governments: Cabinets and Legislatures in Parliamentary Democracies. Cambridge; New York: Cambridge University Press. León, Sandra. 2010. “Who Is Responsible for What? Clarity of Responsibilities in Multilevel States: The Case of Spain.” European Journal of Political Research 50(1):80-109.

León, Sandra. 2018. "Muddling up Political Systems? When Regionalization Blurs Democracy: Decentralization and Attribution of Responsibility.” JCMS: Journal of Common Market Studies 56(3):706-716.

Leonardi, Robert. 2005. Cohesion Policy in the European Union: The Building of Europe. Basingstoke: Palgrave Macmillan.

Marks, Gary, Liesbet Hooghe and Arjan H. Schakel. 2008. "Measuring Regional Authority: A Measure and Five Hypotheses." Regional \& Federal Studies 18(2-3):111-121.

Moury, Catherine. 2011. “Coalition Agreement and Party Mandate: How Coalition Agreements Constrain the Ministers." Party Politics 17(3):385-404.

Müller, Jochen. 2009. “The Impact of the Socio-Economic Context on the Länder Parties' Policy Positions." German Politics 18(3):365-384.

Müller, Jochen. 2013. “On a Short Leash? Sub-National Party Positions between Regional Context and National Party Unity.” Journal of Elections, Public Opinion and Parties 23(2):177- 199.

Müller, Wolfgang C. and Kaare Strøm. 2010. Coalition Agreements and Cabinet Governance. In Cabinets and Coalition Bargaining: The Democratic Life Cycle in Western Europe, ed. Kaare Strom, Wolfgang C. Müller and Torbjörn Bergman. Oxford: Oxford Univ. Press pp. 159-199.

Müller, Wolfgang C. and Thomas M. Meyer. 2010. "Meeting the Challenges of Representation and Accountability in Multi-Party Governments.” West European Politics 33(5):1065-1092.

Müller, Wolfgang C., Torbjörn Bergman and Kaare Strøm. 2010. Coalition Theory and Cabinet Governance: An Introduction. In Cabinets and Coalition Bargaining: The Democratic Life Cycle 
in Western Europe, ed. Kaare Strom, Wolfgang C. Müller and Torbjörn Bergman. Oxford: Oxford Univ. Press pp. 1-50.

Oktay, Sibel. 2018. "Clarity of Responsibility and Foreign Policy Performance Voting." European Journal of Political Research 57(3):587-614.

Pappi, Franz Urban and Nicole Michaela Seher. 2009. "Party Election Programmes, Signalling Policies and Salience of Specific Policy Domains: The German Parties from 1990 to 2005.” German Politics 18(3):403-425.

Powell, G. Bingham JR. and Guy D. Whitten. 1993. "A Cross-National Analysis of Economic Voting: Taking Account of the Political Context." American Journal of Political Science 37(2):391-414.

Renzsch, Wolfgang. 2017. “Vom ‘brüderlichen’ zum ‘väterlichen’ Föderalismus: Zur Neuordnung der Bund-Länder-Finanzbeziehungen ab 2020.” Zeitschrift für Parlamentsfragen 48(4):764772.

Rodden, Jonathan and Erik Wibbels. 2010. "Dual Accountability and the Nationalization of Party Competition: Evidence from Four Federations.” Party Politics 17(5):629-653.Schakel, Arjan H. 2018. "Rethinking European Elections: The Importance of Regional Spillover Into the European Electoral Arena." JCMS: Journal of Common Market Studies 56(3):687-705.

Schermann, Katrin and Laurenz Ennser-Jedenastik. 2014a. "Coalition Policy-Making under Constraints: Examining the Role of Preferences and Institutions." West European Politics 37(3):564-583.

Schermann, Katrin and Laurenz Ennser-Jedenastik. 2014b. "Explaining Coalition-Bargaining Outcomes: Evidence from Austria, 2002-2008.” Party Politics 20(5):564-583.

Schröder, Valentin and Christian Stecker. 2018. "The Temporal Dimension of Issue Competition.” Party Politics 24(6):708-718.

Stecker, Christian. 2015. "Parties on the Chain of Federalism: Position-Taking and Multi-Level Party Competition in Germany." West European Politics 38(6):1305-1326. 
Stefuriuc, Irina. 2009. "Government Formation in Multi-Level Settings: Spanish Regional Coalitions and the Quest for Vertical Congruence.” Party Politics 15(1):93-115.

Strom, Kaare. 2000. "Delegation and Accountability in Parliamentary Democracies." European Journal of Political Research 37(3):261-289.

Strøm, Kaare, Wolfgang C. Müller and Torbjörn Bergman, eds. 2010. Cabinets and Coalition Bargaining: The Democratic Life Cycle in Western Europe. Oxford: Oxford Univ. Press.

Thorlakson, Lori. 2017. "Representation in the EU: Multi-Level Challenges and New Perspectives from Comparative Federalism.” Journal of European Public Policy 24(4):544-561.

Timmermans, Arco I. 2006. "Standing Apart and Sitting Together: Enforcing Coalition Agreements in Multiparty Systems.” European Journal of Political Research 45(2):263-283.

Toubeau, Simon and Markus Wagner. 2018. "Party Support in Multi-Level Elections: The Influence of Economic Perceptions and Vertical Congruence.” Electoral Studies 54:22-34.

Valdini, Melody E. and Michael S. Lewis-Beck. 2018. "Economic Voting in Latin America: Rules and Responsibility." American Journal of Political Science 62(2):410-423.

van Houten, Pieter. 2009. "Multi-Level Relations in Political Parties. A Delegation Approach." Party Politics 15(2):137-156.

Volden, Craig. 2005. "Intergovernmental Political Competition in American Federalism.” American Journal of Political Science 49(2):327-342. 
Appendix

Table 4: Dictionary

\begin{tabular}{|c|c|}
\hline Europe & $\begin{array}{l}\text { maastricht*, lissabon*, ezb, euro*, eu, rettungsschirm*, emf, } \\
\text { binnenmarkt*, euroraum*, mitgliedsstaa*, wirtschaftsunion*, } \\
\text { waehrungsunion*, eu-*, schengen*, *erweiterung }\end{array}$ \\
\hline $\begin{array}{l}\text { Development, Defence, } \\
\text { Foreign, Security }\end{array}$ & $\begin{array}{l}\text { kse*, militaer*, bundeswehr*, soldat*, panzer*, waffe*, wehrpflicht*, } \\
\text { krieg*, weltraum, auslandseinsa*, abruestung*, verteidigung*, friede*, } \\
\text { wehrdienst*, kasern*, wehrtechnisch*, ruestung*, terror*, nato, } \\
\text { afghanistan, osz, nationen, russland, menschenrecht, aussenpolitik, } \\
\text { staaten, menschenrecht*, israel, streitkraeft*, bundesverteidigung* }\end{array}$ \\
\hline $\begin{array}{l}\text { Domestic, } \\
\text { Immigration }\end{array}$ & $\begin{array}{l}\text { rechtsstaat*, polizei*, polizist*, sicherheit*, videoueberwachung*, } \\
\text { ueberwach*, zuwanderung*, bundesinnen*, *extremismus, } \\
\text { grundgesetz, staatsangehoerigkeit*,rechtsstaat, verfassungs*, } \\
\text { schwarzarbeit*, fluechtling*, kriminal*, kriminell*, extremis*, asyl*, } \\
\text { datensch* }\end{array}$ \\
\hline Economy & $\begin{array}{l}\text { privatisier*, regionalpolitik*, energiewirtschaft*, deregulier*, } \\
\text { wirtschaft*, wachstum*, export*, import*, wettbewerb*, } \\
\text { volkswirtschaft*, weltwirtschaft*, marktwirtschaft*, industrie*, } \\
\text { gruender*, selbststaendig*, fachkraft*, fachkraeft*, } \\
\text { vollbeschaeftigung*, unternehme*, kartell*, monopol*, handel*, } \\
\text { gueter*, mittelstand*, mittelstaend*, handwerk*, innovation*, } \\
\text { einzelhandel* }\end{array}$ \\
\hline Education & $\begin{array}{l}\text { bildung*, schule*, hauptschule*, hauptschueler*, schueler*, } \\
\text { realschule*, realschueler*, gymnasium*, gymnasiast*, grundschule*, } \\
\text { grundschueler*, ausbildung*, sonderschule*, sonderschueler*, }\end{array}$ \\
\hline
\end{tabular}




\begin{tabular}{|c|c|}
\hline & $\begin{array}{l}\text { wissenschaft*, forschung, forsche*, universitae*, hochschule*, } \\
\text { exzellenzinitiativ*, studieren*, student*, studierend*, promotion*, } \\
\text { bologna*, bachelor*, master*, post- doc*, professor*, professur*, } \\
\text { forschungszusammenarbeit*, begabtenfoerder*, studienstiftung*, } \\
\text { mint, berufsbildung* }\end{array}$ \\
\hline Transportation, & $\begin{array}{l}\text { logistik*, infrastruktur*, verkehr*, bundesverkehrswegeplan*, } \\
\text { schienen*, radweg*, landstrasse*, bundesstrasse*, autobahn*, } \\
\text { verkehrsschild*, geschwindigkeitsbegrenz*, lkw*, pkw*, maut*, } \\
\text { wegekostengutacht*, vignette*, strasse*, oeffentlich-privat*, oepnv*, } \\
\text { strassenbau*, laermbelastung*, laermbelaestigung*, } \\
\text { verkehrsuebertragend*, bundesfernstrasse*, bundesschienenweg*, } \\
\text { geraeuschminderung*, trasse*, luftverkehr*, schadstoffminderung*, } \\
\text { bestandsnetz*, streckenertuechtigung*, luftfahrt*, flugrout*, } \\
\text { fluggesellschaft*, flughafen*, flughaefe*, flugzeug*, bahn*, } \\
\text { eisenbahn*, bundeswasserstrasse*, hafen*, haefen*, schiff*, nord- } \\
\text { ostsee-kanal*, autogas*, erdgas*, elektromobilitaet*, tankstelle*, } \\
\text { brennstoffzellentechnologie*, carsharing*, fahrrad*, luftraum*, } \\
\text { gueterverkehr*, telekommunikation*, internet*, breitband*, wlan** }\end{array}$ \\
\hline Fiscal & $\begin{array}{l}\text { steuerpol*, erbschaftssteuer*, grundsteuer*, bankenaufsicht*, } \\
\text { bankenunion*, bund-laender-finanzbeziehung*, landesfinanz*, } \\
\text { bundesfinanz*, konsolidier*, finanzstark*, finanzschwach*, finanz*, } \\
\text { landesmittel*, bundesmittel*, solidarpakt*, haushalt*, staatsfinanz*, } \\
\text { schuldenbremse* }\end{array}$ \\
\hline Welfare, Family, Health & $\begin{array}{l}\text { droge*, sucht*, *sucht, grundsich*, erziehung*, familien*, kindertag*, } \\
\text { kindersch*, kinderrecht*, mehrgeneration*, jugendsch*, eltern*, }\end{array}$ \\
\hline
\end{tabular}




\begin{tabular}{|c|c|}
\hline & $\begin{array}{l}\text { alleinerziehend*, kinderbetr*, arbeitslosenversicherung*, hartz*, } \\
\text { rente*, pension*, sozialpolitik*, sozialbudget*, armut*, } \\
\text { gesundheitsversorgung*, pflege*, patient*, medizinisch*, medizin*, } \\
\begin{array}{l}\text { kranken*, diagnose*, arzt*, aerzt*, ambulant*, stationaer*, } \\
\text { psychotherapeut*, }\end{array} \text { praxisnetz*, } \\
\begin{array}{l}\text { behandlungstermin*, hausarzt*, hausaerztlich, hausaerzt*, facharzt*, } \\
\text { fachaerzt*, arznei*, heilmittel*, mehrfachbehinderung*, }\end{array} \\
\text { gesundheitsberuf*, klinik*, universitaetsklinik*, apotheke*, } \\
\text { psychiatrie*, psychosomatik*, }{ }^{*} \text { pflege, landarzt*, landaerzt* }\end{array}$ \\
\hline $\begin{array}{l}\text { Environment, } \\
\text { Climate }\end{array}$ & $\begin{array}{l}\text { natur*, solar*, windenergie, windkraft, EEG, bio*, } \\
\text { gebaeudesanierung, erneuerbar*, energie*, treibhaus*, CO*, } \\
\text { emission*, klima*, erderwaermung, nachhaltigkeit, umwelt*, } \\
\text { kohlenstoffdioxid*, umweltverschm*, atom*, radioaktiv*, *gift*, } \\
\text { kohle*, braunkohle*, endlag*, nuklear*, geotherm*, steinkohle*, } \\
\text { pflanzenschutzmittel*, verbraucher*, bauern*, landwirt*, agrar*, } \\
\text { lebensmittel*, fleisch*, tierschutz*, kernenergie* }\end{array}$ \\
\hline Justice & $\begin{array}{l}\text { richte*, } \text { gericht* }^{*}, \quad \text { strafma*, } \\
\text { bundesverfassungsgericht*, } \\
\text { landesgericht*, }\end{array}$ \\
\hline
\end{tabular}

